\title{
Determinants of health care use among homeless individuals: evidence from the Hamburg survey of homeless individuals
}

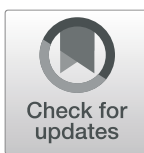

\author{
André Hajek ${ }^{1 *}$, Franziska Bertram², Fabian Heinrich², Victoria van Rüth², Benjamin Ondruschka², Benedikt Kretzler ${ }^{1}$, \\ Christine Schüler ${ }^{3}$, Klaus Püschel ${ }^{2+}$ and Hans-Helmut König ${ }^{1+}$
}

\begin{abstract}
Background: To identify the determinants of health care use among homeless individuals.

Methods: Data were taken from the Hamburg survey of homeless individuals ( $n=100$ individuals in the here used model, mean age 44.8 years, SD 12.5) focusing on homeless individuals in Hamburg, Germany. The number of physician visits in the past 3 months and hospitalization in the preceding 12 months were used as outcome measures. Drawing on the Andersen model of health care use as a conceptual framework, predisposing characteristics, enabling resources and need factors as well as psychosocial variables were included as correlates.

Results: Negative binomial regressions showed that increased physician visits were associated with being female (IRR: 4.02 [95\% Cl: 1.60-10.11]), absence of chronic alcohol consume (IRR: 0.26 [95\% Cl: 0.12-0.57]) and lower healthrelated quality of life (IRR: 0.97 [95\% Cl: 0.96-0.98]). Furthermore, logistic regressions showed that the likelihood of hospitalization was positively associated with lower age (OR: 0.93 [95\% Cl: $0.89-0.98]$ ), having health insurance (OR: 8.11 [2.11-30.80]) and lower health-related quality of life (OR: 0.97 [95\% Cl: 0.94-0.99]).

Conclusions: Our study showed that predisposing characteristics (both age and sex), enabling resources (i.e., health insurance) and need factors in terms of health-related quality of life are main drivers of health care use among homeless individuals. This knowledge may assist in managing health care use.
\end{abstract}

Keywords: Andersen's behavioral model, Health care use, Health care utilization, Homeless, Corona-virus, COVID-19, SARS-CoV-2

\section{Background}

In sum, about 678,000 homeless individuals lived in Germany in the year 2018 [1]. In the second largest city in Germany, Hamburg, about 6600 homeless individuals resided [2]. Moreover, the number of individuals is steadily increasing [1]. Key health-related characteristics of homeless individuals are high prevalence rates of

\footnotetext{
* Correspondence: a.hajek@uke.de

${ }^{\dagger}$ Klaus Püschel and Hans-Helmut König contributed equally to this work. 1 Department of Health Economics and Health Services Research, University Medical Center Hamburg-Eppendorf, Hamburg, Germany

Full list of author information is available at the end of the article
}

mental disorders and infectious diseases (e.g., contracting HIV, and hepatitis B and C infections [3]). Furthermore, high prevalence rates of cardiovascular and respiratory diseases have been reported [4]. Moreover, they have a high prevalence of substance use disorders [5]. Premature death is frequent in this group [6].

Use of health care services is particularly important for the health of homeless individuals. However, only a few studies have examined the determinants of health care use among homeless individuals in German cities [7-11] mainly showing that medical services were mostly used in critical and acute situations and continued treatment

(c) The Author(s). 2021 Open Access This article is licensed under a Creative Commons Attribution 4.0 International License, which permits use, sharing, adaptation, distribution and reproduction in any medium or format, as long as you give appropriate credit to the original author(s) and the source, provide a link to the Creative Commons licence, and indicate if changes were made. The images or other third party material in this article are included in the article's Creative Commons licence, unless indicated otherwise in a credit line to the material. If material is not included in the article's Creative Commons licence and your intended use is not permitted by statutory regulation or exceeds the permitted use, you will need to obtain permission directly from the copyright holder. To view a copy of this licence, visit http://creativecommons.org/licenses/by/4.0/ The Creative Commons Public Domain Dedication waiver (http://creativecommons.org/publicdomain/zero/1.0/) applies to the data made available in this article, unless otherwise stated in a credit line to the data. 
rarely followed [10]. Previous international studies examining health care use among homeless individuals mostly came from North American countries such as Canada or the United States - and focused on specific topics. For instance, studies focused on oral health for homeless individuals in Vancouver [12], the use of a mobile health unit in Toronto [13], examined individuals from their entry into a homeless shelter system in New York City through the next 1.5 years [14] or investigated health care use of homeless veterans in Chicago [15]. Moreover, based on a sample of 2974 homeless persons in the United States (homeless assistance program; a nationally representative survey), Kushel et al. [16] showed that nearly $63 \%$ of individuals had one or more ambulatory care visits in the past year, about $32 \%$ of individuals visited an emergency department (ED) and more than 23\% of individuals had a hospital stay. In contrast, nearly $25 \%$ were unable to receive required medical care. Particularly having health insurance was positively associated with use of ambulatory care, inpatient hospitalization, whereas it was negatively associated with barriers to required care. Furthermore, it was not associated with ED visits. A further study from Toronto, Ontario ( $n=1165$ homeless single men and women and adults in families) under a universal health insurance system showed that homeless people had markedly higher rates of ED and hospital use compared to matched controls. It should be noted that the rates were mainly driven by a subset of homeless individuals with very high use of health services [17].

A comparable recent study found that a large variety of factors (including mental health problems) predict health care use [18]. Since there is a gap in knowledge regarding health care use among homeless individuals, the aim of this study was to identify the main determinants of health care use (in terms of both physician visits and hospitalization) among homeless individuals in Hamburg, Germany.

While there may be cultural differences between Hamburg, Germany and other areas of the world, we believe that homeless populations are often characterized by traumatizing experiences, and - more broadly similar socioeconomic and health-related factors which may be similarly associated with healthcare use in other countries.

According to the Andersen model of health care utilization [19], the determinants of health care can be distinguished into predisposing characteristics such as country of origin, sex or age, enabling resources such as perceived access and need factors such as health-related quality of life or chronic conditions.

More precisely, predisposing characteristics mainly cover social factors such as educational level or "biological factors" such as sex or chronological age.
Moreover, contextual predisposing factors include, for example, cultural norms. Enabling resources cover organizational and financial factors which might be associated with health care use. For instance, individual financing factors can include wealth or income (e.g., for out-of-pocket payments). Organizational factors can include transportation or travel time. Additionally, contextual factors include, for example, density of physicians or hospitals. Moreover, it can be distinguished between evaluated need (such as chronic conditions diagnosed by physicians) and individual need (such as self-rated health) [20].

Furthermore, it has recently been proposed [21] to extend this model by adding psychosocial factors (such as loneliness, social isolation, life satisfaction, self-esteem or locus of control). Adjusting for predisposing characteristics, enabling resources and need factors, some empirical previous studies also demonstrated that psychosocial factors are important for health care use [22-26]. Since, for example, some recent studies revealed postponed access to medical services (most likely for reasons of COVID-19) [27, 28], it seems reasonable to include such a factor in our current study.

This study may assist in managing health care use and was designed to answer determinants of health care use among homeless individuals.

\section{Materials and methods \\ Cohort description}

We used data from a prospective study focusing on living conditions and health care situations of 151 homeless adults in Hamburg ("Hamburg survey of homeless individuals"), Germany. Personal interviews were conducted in night shelters, lodging houses and specialized medical practices from end of May to early June 2020 (25th May to 3rd June) using a separate room. While three individuals refused participation after initial agreement, 151 individuals took part (response rate: 98\%). In sum, 100 individuals were included in the analytical sample (due to single missing values in the rest).

The visitation includes, among other things, a blood withdrawal, a physical examination, demographic information, and a questionnaire-based interview (including information about health care use). Due to problems in reading and understanding the questions, most individuals were interviewed (face-to-face) and a few individuals (without these difficulties) filled out the questionnaire independently.

All individuals provided their written and informed consent prior to their participation. The study design and content was approved by the Ethics Committee of the medical council of Hamburg (application number: PV7333). 


\section{Dependent variables}

Health care use was assessed covering (1) outpatient physician visits and (2) hospital treatment. The self-rated number of physician visits in the past 3 months was used as outcome measure. Moreover, the self-rated number of hospital visits in the preceding 12 months was assessed. Finally, data were dichotomized for this study (no hospital stay; at least one hospital stay).

\section{Independent variables}

Drawing on the Andersen model of health care use as a conceptual framework, predisposing characteristics of the individuals, enabling resources and need factors were included as correlates. Furthermore, as recently proposed [21], we also added a very recent psychosocial factor in asking about fear of COVID-19.

As regards predisposing characteristics, we included age, sex (women or men), marital status (single vs. others (divorced; widowed; married)), educational level (according to the CASMIN classification: primary, secondary and tertiary education [29]), country of origin (Germany; neighboring country; other European country) and chronic alcohol consumption (carbohydrate-deficient transferrin $\quad(\mathrm{CDT}>2.5$ refers to elevated) [30, 31]).

With regard to enabling resources, the potential presence of health insurance (no; yes) was included. With regard to need factors, health-related quality of life was included as need factor. It was quantified using the EQVAS ranging from 0 (worst) to 100 (best) [32]. Furthermore, fear of COVID-19 (from $1=$ not at all to $4=$ severely) was used as psychosocial factor.

\section{Statistical analysis}

First, the analytical sample was described. Subsequently, negative binomial regressions were used (with physician visits as outcome measure) because of the nature of the data (distribution of physician visits was positively skewed) [33-35]. Hardin et al. provide further details regarding these regression models [35]. In case of hospitalization (no; yes), a logistic regression model was used. Predisposing characteristics, enabling resources and need factors were simultaneously included in this regression model. The criterion for statistical significance was set at $p<0.05$. Analyses were performed using Stata 16.0 (StataCorp, College Station, Texas, USA).

\section{Results}

\section{Sample characteristics}

The analytical sample is described in Table 1. In sum, average age was 44.8 years (SD 12.5; ranging from 22 to 71 years) and most individuals were male (80\%). The average number of physician visits in the past 3 months equaled 3.5 (SD 10.2 visits; from 0 to 90 visits; $44.9 \%$ of
Table 1 Sample characteristics $(n=100)$

\begin{tabular}{|c|c|}
\hline Independent variables & $\begin{array}{l}\text { Mean (SD) / n } \\
\text { (\%) }\end{array}$ \\
\hline \multicolumn{2}{|l|}{ Gender } \\
\hline Male & $80(80.0 \%)$ \\
\hline Female & $20(20.0 \%)$ \\
\hline Age & $44.8(12.5)$ \\
\hline \multicolumn{2}{|l|}{ Family status } \\
\hline Single & $67(67.0 \%)$ \\
\hline $\begin{array}{l}\text { Widowed/Divorced/Married, living separated from } \\
\text { spouse }\end{array}$ & $33(33.0 \%)$ \\
\hline \multicolumn{2}{|l|}{ Education } \\
\hline Primary education & $34(34.0 \%)$ \\
\hline Secondary/tertiary education & $66(66.0 \%)$ \\
\hline \multicolumn{2}{|l|}{ Country of origin } \\
\hline Germany & $52(52.0 \%)$ \\
\hline Neighboring country & $23(23.0 \%)$ \\
\hline Other European country & $25(25.0 \%)$ \\
\hline \multicolumn{2}{|l|}{ Alcohol consume } \\
\hline Absence of chronic alcohol consume (CDT $\leq 2.5)$ & $63(63.0 \%)$ \\
\hline Presence of chronic alcohol consume (CDT > 2.5) & $37(37.0 \%)$ \\
\hline \multicolumn{2}{|l|}{ Health insurance } \\
\hline Yes, having health insurance & $69(69.0 \%)$ \\
\hline No, not having health insurance & $31(31.0 \%)$ \\
\hline Fear of COVID-19 (from $1=$ not at all to $4=$ severely) & $1.8(1.0)$ \\
\hline $\begin{array}{l}\text { Health-related quality of life (EQ VAS, ranging from } 0 \\
\text { (worst) to } 100 \text { (best)) }\end{array}$ & $75.5(21.0)$ \\
\hline Number of physician visits within 3 months & $3.5(10.2)$ \\
\hline \multicolumn{2}{|l|}{ Hospitalization within 3 months } \\
\hline No hospital visits & $58(58.0 \%)$ \\
\hline At least one hospital visit & $42(42.0 \%)$ \\
\hline
\end{tabular}

the individuals without physician visits) and $42 \%$ of the individuals reported at least one hospital visit in the past 12 months. Further details are given in Table 1 .

\section{Regression analysis}

The results of negative binomial regressions (with physician visits as outcome measure) are presented in Table 2 . Negative binomial regressions showed that increased physician visits were associated with being female (IRR: 4.02 [95\% CI: 1.60-10.11]), absence of chronic alcohol consume (IRR: 0.26 [95\% CI: 0.12-0.57]) and lower health-related quality of life (IRR: 0.97 [95\% CI: 0.96$0.98]$ ). In contrast, the outcome measure was not significantly associated with age, family status, educational level and fear of COVID-19.

The findings of logistic regressions (with hospitalization as outcome measure) are displayed in Table 3. Logistic regressions showed that the likelihood of hospitalization was 
Table 2 Determinants of the frequency of physician visits in the past 3 months. Findings of multiple negative binomial regressions

\begin{tabular}{|c|c|}
\hline Independent variables & $\begin{array}{l}\text { Number of doctor } \\
\text { visits }\end{array}$ \\
\hline \multirow[t]{2}{*}{ Gender: - Female (Ref.: Male) } & $4.02^{* *}$ \\
\hline & $(1.60-10.11)$ \\
\hline \multirow[t]{2}{*}{ Age } & 0.99 \\
\hline & $(0.96-1.02)$ \\
\hline \multirow{2}{*}{$\begin{array}{l}\text { Family status: - Widowed/Divorced/Married, living } \\
\text { separated from spouse (Ref.: Single) }\end{array}$} & 0.88 \\
\hline & $(0.46-1.67)$ \\
\hline \multirow{2}{*}{$\begin{array}{l}\text { Education: - Secondary/tertiary education (Ref.: } \\
\text { Primary education) }\end{array}$} & 1.59 \\
\hline & $(0.76-3.32)$ \\
\hline \multirow{2}{*}{$\begin{array}{l}\text { Country of origin: - Neighboring country } \\
\text { (Germany) }\end{array}$} & 2.11 \\
\hline & $(0.79-5.64)$ \\
\hline \multirow[t]{2}{*}{ - Other country } & 0.78 \\
\hline & $(0.41-1.49)$ \\
\hline \multirow{2}{*}{$\begin{array}{l}\text { Alcohol consume: - Presence of chronic alcohol } \\
\text { consume (CDT > 2.5) (Ref.: Absence of chronic } \\
\text { alcohol consume) }\end{array}$} & $0.26^{* * *}$ \\
\hline & $(0.12-0.57)$ \\
\hline \multirow{2}{*}{$\begin{array}{l}\text { Health insurance: Yes (Reference category: No } \\
\text { health insurance) }\end{array}$} & 0.70 \\
\hline & $(0.34-1.48)$ \\
\hline \multirow{2}{*}{$\begin{array}{l}\text { Fear of COVID-19 (from } 1=\text { not at all to } 4= \\
\text { severely) }\end{array}$} & 1.06 \\
\hline & $(0.75-1.50)$ \\
\hline \multirow{2}{*}{$\begin{array}{l}\text { Health-related quality of life (EQ-VAS, ranging from } \\
0 \text { (worst) to } 100 \text { (best)) }\end{array}$} & $0.97^{* * *}$ \\
\hline & $(0.96-0.98)$ \\
\hline \multirow[t]{2}{*}{ Constant } & $11.06^{*}$ \\
\hline & $(1.05-116.15)$ \\
\hline Pseudo $R^{2}$ & 0.10 \\
\hline Observations & 98 \\
\hline
\end{tabular}

Incidence rate ratios are reported. 95\% confidence intervals in parentheses. *** $p<0.001,{ }^{* *} p<0.01,{ }^{*} p<0.05,+p<0.10$

positively associated with lower age (OR: 0.93 [95\% CI: 0.89-0.98]), having health insurance (OR: 8.11 [2.1130.80]) and lower health-related quality of life (OR: 0.97 [95\% CI: 0.94-0.99]), whereas it was not significantly associated with sex, family status, educational level, country of origin, alcohol consume and fear of COVID-19.

\section{Discussion}

Based on recent data of homeless individuals, the authors here provide very first evidence regarding determinants of health care use in this vulnerable group exemplified for the metropolitan city Hamburg, Germany. Main results showed that increased physician visits were associated with being female, absence of chronic alcohol consume objectified by laboratory measures and lower health-related quality of life. Moreover, the likelihood of hospitalization was positively associated
Table 3 Determinants of hospitalization in the past 12 months ( $0=$ no hospital visits; $1=$ yes, at least one hospital visit).

Findings of multiple logistic regressions

\begin{tabular}{|c|c|}
\hline Independent variables & Hospitalization \\
\hline \multirow[t]{2}{*}{ Gender: - Female (Ref:. Male) } & 1.14 \\
\hline & $(0.33-3.90)$ \\
\hline \multirow[t]{2}{*}{ Age } & $0.93^{* *}$ \\
\hline & $(0.89-0.98)$ \\
\hline \multirow{2}{*}{$\begin{array}{l}\text { Family status: - Widowed/Divorced/Married, living } \\
\text { separated from spouse (Ref.: Single) }\end{array}$} & $2.42+$ \\
\hline & $(0.87-6.72)$ \\
\hline \multirow{2}{*}{$\begin{array}{l}\text { Education: - Secondary/tertiary education (Ref.: Primary } \\
\text { education) }\end{array}$} & 0.91 \\
\hline & $(0.31-2.70)$ \\
\hline \multirow[t]{2}{*}{ Country of origin: - Neighboring country (Germany) } & 2.68 \\
\hline & $(0.59-12.17)$ \\
\hline \multirow[t]{2}{*}{ - Other country } & 0.93 \\
\hline & $(0.26-3.38)$ \\
\hline \multirow{2}{*}{$\begin{array}{l}\text { Alcohol consume: - Presence of chronic alcohol } \\
\text { consume (CDT > 2.5) (Ref.: Absence of chronic alcohol } \\
\text { consume) }\end{array}$} & 0.82 \\
\hline & $(0.25-2.68)$ \\
\hline \multirow{2}{*}{$\begin{array}{l}\text { Health insurance: Yes (Reference category: No health } \\
\text { insurance) }\end{array}$} & $8.11^{* *}$ \\
\hline & $(2.13-30.80)$ \\
\hline \multirow[t]{2}{*}{ Fear of COVID-19 (from $1=$ not at all to $4=$ severely) } & 0.95 \\
\hline & $(0.58-1.56)$ \\
\hline \multirow{2}{*}{$\begin{array}{l}\text { Health-related quality of life (EQ VAS, ranging from } \\
0 \text { (worst) to } 100 \text { (best)) }\end{array}$} & $0.97^{* *}$ \\
\hline & $(0.94-0.99)$ \\
\hline \multirow[t]{2}{*}{ Constant } & 19.47 \\
\hline & $(0.49-775.21)$ \\
\hline Pseudo $R^{2}$ & 0.22 \\
\hline Observations & 100 \\
\hline
\end{tabular}

Odds ratios are reported. $95 \%$ confidence intervals in parentheses. ${ }^{* *} p<$ $0.001,{ }^{* *} p<0.01,{ }^{*} p<0.05,+p<0.10$

with lower age, having health insurance and lower health-related quality of life.

It should be noted that the number of physician visits is only slightly higher compared to the general population in Germany (average number of physician visits in the preceding 3 months: 2.8 , SD 3.8) [36]. The main reason for this observation could potentially be explained by high risk lifestyle of some homeless people and being exposed to critical external influences.

Moreover, the access to healthcare services is quite good in Hamburg, Germany. For example, about two out of third homeless individuals had health insurance in our sample. While the average number of physician visits in the past 3 months equaled 4.1 visits (SD: 12.0) among homeless individuals with health insurance in our sample, it equaled 2.1 visits (SD: 3.9 ) among homeless individuals without health insurance. The good supply of mobile support services (e.g., rolling doctor's office) may also explain these findings. 
In contrast, the proportion of individuals with at least one hospital visit in the past year is markedly higher compared to the general population in Germany (where only $12.6 \%$ were hospitalized in the previous 12 months) [36] and most comparable to the proportion of hospital stays among the geriatric population in Germany $(25.1 \%$ of the individuals reported at least one hospital stay in the past 6 months) [37]. Ignoring banal diseases on the streets and in daily life might result in exacerbation and thus, potentially more critical progressions with the necessity for hospitalization.

The positive association between frequency of physician visits and being female may be explained by the fact that homeless women may generally have a higher compliance and body awareness. They may have an increased willingness to stay healthy by using health care services - as frequently shown by studies focusing on the general population [20]. However, future research is required to clarify this association among homeless individuals in further detail. Illustrating distinct sexassociated differences in decision progress for or against physician visits were beyond the scope of this manuscript.

The link between an increased number of physician visits and the absence of chronic alcohol consume may be explained by the fact that individuals with a chronic alcohol consume may underestimate their health risks in general and their substance abuse in detail. For example, it has been demonstrated that alcohol addiction is positively associated with fatalism and feelings of invulnerability [38]. In sum, individuals with a chronic alcohol consume may therefore avoid physician visits resulting in progression of alcohol-associated organopathies.

Previous research mainly showed a link between increased needs and the number of physician visits in a variety of cohorts [39-41]. Thus, our findings with regard to the association between health-related quality of life and physician visits are well in accordance with previous research. This association can be simply explained by the fact that signs of an illness or certain symptoms were identified by the individuals and consequently the individuals are willing to check their symptoms by physicians [42]. An analogous mechanism may explain the link between health-related quality of life and hospitalization and is in line with studies using data from the general population in later decades $[42,43]$.

A higher likelihood of hospitalization among homeless individuals was associated with younger age in our study. We assume that younger homeless individuals may have a higher compliance regarding hospital stays compared to older individuals [44]. Moreover, younger homeless individuals may be more prone to risky behavior and alcohol poisoning or other substance use [45]. Similarly, it has been shown that conscientiousness is lower in younger age [46]. Furthermore, it has been shown that conscientiousness is associated with a lower risk of hospitalization [41]. Therefore, our findings appears plausible. However, future research in this area is required.

Additionally, there was a relevant association between having health insurance and hospitalization. This is in accordance with previous research among homeless individuals from California, US [47]. Homeless individuals not having health insurance may fear accessing hospitals (e.g., because of not being treated or being applied for payment). However, future studies (e.g., qualitative studies) are required to elucidate the underlying mechanisms exactly.

It should be noted that fear of COVID-19 was not associated with the outcome measures. Thus, use of inand outpatient health care services (in terms of physician visits and hospitalization) is not driven by this very recent psychosocial factor. Given that recent studies showed postponed or delayed access to medical services $[27,28]$, partly due to fear of COVID-19, these findings are unexpected. A possible explanation for this missing association may be that fear of COVID-19 most likely only refers to the past few months, whereas hospitalization in the past 12 months was assessed. Moreover, fear of COVID-19 may be of limited importance when homeless individuals are in urgent need of care. However, future studies, e.g., based on qualitative approaches, are required to clarify why fear of COVID19 does not drive health care use among homeless individuals and also if feelings on this pandemic phase of life changes with the second wave of infections overwhelms the world.

Several strengths and limitations of this approach are worth mentioning. First, data was used from a difficult to access and vulnerable population during the COVID19 pandemic. However, the response rate was very high. Nevertheless, a considerable amount of missing values (mainly due to language barriers or unwillingness to answer the questions) should be noted resulting in reduction of the overall study population to a $2 / 3$ cohort presented here. Using self-reports of health care use may introduce some recall bias. However, the recall periods have been selected in accordance with common recommendations [48]. Intentionally, the question on chronic alcohol abuse was answered with laboratory methods measuring CDT. Generally, plain and simple language was used to avoid misunderstandings during the interview [2]. We assume that our findings cannot be generalized to homeless individuals with very severe health impairments and to other regions of the world with sometimes very different national healthcare systems and supporting features. Moreover, generalizing our findings to other countries may at least be difficult, for 
example due to differences in access to healthcare services (in general and for homeless populations). Due to the cross-sectional nature of this study, the authors cannot dismiss the possibility that the potential direction of these associations is reversed. Moreover, additional psychosocial or personality-related determinants be included in future research [22, 40, 49]. Furthermore, other factors (e.g., other substance use disorders, health literacy, lack of transportation, cognitive functioning or perceived discrimination in health care settings) might be of importance for health care use [16, 17]. However, these factors were not included for reasons of data availability. Nevertheless, future studies should clarify the role of these factors for health care use. Additionally, it should be noted that alcohol intake was classified as predisposing characteristic [50, 51]. However, this is debatable and former studies also classified it as need factor $[52,53]$.

\section{Conclusion}

This given study showed that predisposing characteristics (age or sex), enabling resources (i.e., health insurance) and need factors in terms of health-related quality of life are main drivers of health care use among homeless individuals. This knowledge may assist in managing health care use for this special but highly relevant population group.

\section{Abbreviations \\ CDT: Carbohydrate-deficient transferrin; Cl: Confidence interval; COVID- 19: Coronavirus disease 2019; EQ-VAS: EuroQol-Visual analogue scale; IRR: Incidence rate ratio; OR: Odds ratio; Ref: Reference category; $R^{2}$ : Coefficient of determination; SARS-CoV-2: Acute respiratory syndrome coronavirus 2; SD: Standard deviation}

\section{Acknowledgements}

None.

\section{Strobe}

All methods were performed in accordance with the STROBE (Strengthening the reporting of observational studies in epidemiology) Statement.

\section{Authors' contributions}

Conceptualization, K.P., F.B., F.H., A.H., H.-H.K.; methodology/formal analysis, A.H.; writing-original draft preparation, A.H.; writing-review and editing, A.H., F.B., V.v.R., C. S., B.O., B.K., K.P., F.H., H.-H.K.; supervision, H.-H.K.; funding acquisition, F.H. All authors have read and agreed to the published version of the manuscript.

\section{Funding}

The study was made financially possible by uncommitted private donations to the University Medical Centre Hamburg-Eppendorf. Open Access funding enabled and organized by Projekt DEAL.

\section{Availability of data and materials}

The datasets analysed during the current study are not publicly available due to ethical restrictions involving patient data but are available from the corresponding author on reasonable request.

\section{Declarations}

\section{Ethics approval and consent to participate}

The study was conducted in accordance with the Declaration of Helsinki and the ethical statement was obtained from the medical council of Hamburg (application number: PV7333). Prior to investigation, all individuals gave their written informed consent.

\section{Consent for publication}

Not applicable.

\section{Competing interests}

The authors declare that they have no competing interests.

\section{Author details}

${ }^{1}$ Department of Health Economics and Health Services Research, University Medical Center Hamburg-Eppendorf, Hamburg, Germany. ${ }^{2}$ Institute of Legal Medicine, University Medical Center Hamburg-Eppendorf, Hamburg, Germany. ${ }^{3}$ Deutsches Rotes Kreuz Kreisverband Hamburg Altona und Mitte e.V, Hamburg, Germany.

Received: 3 November 2020 Accepted: 22 March 2021

Published online: 07 April 2021

\section{References}

1. Federal Association for Assistance to Homeless People (BAGW). Zahl der Wohnungslosen [Number of homeless individuals]: Federal Association for Assistance to Homeless People (BAGW); 2019. p. 1-4.

2. Ratzka M, Kämper A. Befragung obdachloser, auf der Straße lebender Menschen und wohnungsloser, öffentlichrechtlich untergebrachter Haushalte 2018 in Hamburg. Auswertungsbericht: GOE Bielefeld; 2018.

3. Raoult D, Foucault C, Brouqui P. Infections in the homeless. Lancet Infect Dis. 2001;1(2):77-84. https://doi.org/10.1016/S1473-3099(01)00062-7.

4. Aldridge RW, Story A, Hwang SW, Nordentoft M, Luchenski SA, Hartwell G, et al. Morbidity and mortality in homeless individuals, prisoners, sex workers, and individuals with substance use disorders in high-income countries: a systematic review and meta-analysis. Lancet. 2018;391(10117):241-50. https://doi.org/10.1016/S0140-6736(17)31869-X.

5. Fazel $S$, Geddes JR, Kushel M. The health of homeless people in highincome countries: descriptive epidemiology, health consequences, and clinical and policy recommendations. Lancet. 2014;384(9953):1529-40. https://doi.org/10.1016/S0140-6736(14)61132-6.

6. O'Connell JJ. Premature mortality in homeless populations: a review of the literature: National Health Care for the Homeless Council; 2005. p. 2005-16.

7. Doering TJ, Hermes E, Konitzer M, Fischer GC, Steuernagel B. [Health situation of homeless in a health care home in Hannover]. Gesundheitswesen 2002, 64(6):375-382, DOI: https://doi.org/10.1055/s-2 002-32176.

8. Kimont $\mathrm{HG}$, Leidel J. [Basic medical care of drug dependent patients and young homeless persons--a report from general practice]. Gesundheitswesen 1994, 56(10):505-508.

9. Leidel I, Kimont HG, Berger H. [Medical management of homeless persons]. Gesundheitswesen 1998, 60 Suppl 1:S41-S46.

10. Meller I, Fichter M, Quadflieg N, Koniarczyk M, Greifenhagen A, Wolz J. [Utilization of medical and psychosocial services by mentally ill homeless persons. Results of an epidemiological study]. Nervenarzt 2000, 71(7):543551, DOI: https://doi.org/10.1007/s001150050624.

11. Trabert G. Medizinische Versorgung für wohnungslose Menschenindividuelles Recht und soziale Pflicht statt Exklusion. Das Gesundheitswesen. 2016;78(02):107-12.

12. Mago A, Brondani MA, MacEntee MI, Frankish CJ. A model pathway to oral health care for homeless people. J Can Dent Assoc. 2018;84:i10.

13. Whelan C, Chambers C, Chan M, Thomas S, Ramos G, Hwang SW. Why do homeless people use a mobile health unit in a country with universal health care? J Prim Care Community Health. 2010;1(2):78-82. https://doi. org/10.1177/2150131910372233.

14. Schanzer B, Dominguez B, Shrout PE, Caton CL. Homelessness, health status, and health care use. Am J Public Health. 2007:97(3):464-9. https://doi.org/1 0.2105/AJPH.2005.076190. 
15. Raad JH, Tarlov E, Kho AN, French DD. Health care utilization among homeless veterans in Chicago. Mil Med. 2020;185(3-4):e335-9. https://doi. org/10.1093/milmed/usz264.

16. Kushel MB, Vittinghoff E, Haas JS. Factors associated with the health care utilization of homeless persons. JAMA. 2001;285(2):200-6. https://doi.org/1 0.1001/jama.285.2.200.

17. Hwang SW, Chambers C, Chiu S, Katic M, Kiss A, Redelmeier DA, et al. A comprehensive assessment of health care utilization among homeless adults under a system of universal health insurance. Am J Public Health. 2013;103(S2):S294-301. https://doi.org/10.2105/AJPH.2013.301369.

18. Petrovich JC, Hunt JJ, North CS, Pollio DE, Roark Murphy E. Comparing unsheltered and sheltered homeless: demographics, health services use and predictors of health services use. Community Ment Health J. 2020;56(2):2719. https://doi.org/10.1007/s10597-019-00470-0.

19. Andersen R, Newman JF. Societal and individual determinants of medical care utilization in the United States. Milbank Mem Fund Q Health Soc. 1973; 51(1):95-124. https://doi.org/10.2307/3349613.

20. Babitsch B, Gohl D, von Lengerke T: Re-revisiting Andersen's behavioral model of health services use: a systematic review of studies from 19982011. GMS Psycho Soc Med 2012, 9.

21. Hajek A, König $\mathrm{H}-\mathrm{H}$. Beyond symptoms: why do patients see the doctor? BJGP Open. 2020;4(2):bjgpopen20X101088.

22. Bock JO, Hajek A, König HH. The longitudinal association between psychological factors and health care use. Health Serv Res. 2018;53(2):106591. https://doi.org/10.1111/1475-6773.12679.

23. Burns A, Leavey G, Ward M, O'Sullivan R. The impact of loneliness on healthcare use in older people: evidence from a nationally representative cohort. J Public Health. 2020;1-10. https://doi.org/10.1007/s10389-020-0133 8-4.

24. Cruwys T, Wakefield JR, Sani F, Dingle GA, Jetten J. Social isolation predicts frequent attendance in primary care. Ann Behav Med. 2018;52(10):817-29. https://doi.org/10.1093/abm/kax054

25. Hajek A, Bock J-O, König H-H. Association of general psychological factors with frequent attendance in primary care: a population-based crosssectional observational study. BMC Fam Pract. 2017;18(1):1-9.

26. Lim KK, Chan A. Association of loneliness and healthcare utilization among older adults in Singapore. Geriatr Gerontol Int. 2017;17(11):1789-98. https:// doi.org/10.1111/ggi.12962

27. Lazzerini M, Barbi E, Apicella A, Marchetti F, Cardinale F, Trobia G. Delayed access or provision of care in Italy resulting from fear of COVID-19. Lancet Child Adolesc Health. 2020;4(5):e10-1. https://doi.org/10.1016/S2352-4642 (20)30108-5

28. Lynn RM, Avis JL, Lenton S, Amin-Chowdhury Z, Ladhani SN. Delayed access to care and late presentations in children during the COVID-19 pandemic: a snapshot survey of 4075 paediatricians in the UK and Ireland. Arch Dis Child. 2020;106(2):e8.

29. Brauns H, Steinmann S. Educational reform in France, West-Germany and the United Kingdom: updating the CASMIN educational classification. ZUMA Nachrichten. 1999;23(44):7-44.

30. Bortolotti F, Sorio D, Bertaso A, Tagliaro F. Analytical and diagnostic aspects of carbohydrate deficient transferrin (CDT): a critical review over years 2007 2017. J Pharm Biomed Anal. 2018;147:2-12. https://doi.org/10.1016/j.jpba.2 017.09.006.

31. Stibler H. Carbohydrate-deficient transferrin in serum: a new marker of potentially harmful alcohol consumption reviewed. Clin Chem. 1991;37(12): 2029-37. https://doi.org/10.1093/clinchem/37.12.2029.

32. EuroQol Group. EuroQol--a new facility for the measurement of healthrelated quality of life. Health Policy. 1990;16(3):199-208.

33. Afifi AA, Kotlerman JB, Ettner SL, Cowan M. Methods for improving regression analysis for skewed continuous or counted responses. Annu Rev Public Health. 2007;28(1):95-111. https://doi.org/10.1146/annurev.publhea Ith.28.082206.094100.

34. Atkins DC, Gallop RJ. Rethinking how family researchers model infrequent outcomes: a tutorial on count regression and zero-inflated models. J Fam Psychol. 2007;21(4):726-35. https://doi.org/10.1037/0893-3200.21.4.726.

35. Hardin JW, Hardin JW, Hilbe JM, Hilbe J. Generalized linear models and extensions: Stata Press; 2007.

36. Hajek A, Bock J-O, König H-H. The role of personality in health care use: results of a population-based longitudinal study in Germany. PLoS One. 2017;12(7):e0181716. https://doi.org/10.1371/journal.pone.0181716.
37. Hajek A, Brettschneider C, Eisele M, Kaduszkiewicz H, Mamone S, Wiese B, et al. Correlates of hospitalization among the oldest old: results of the AgeCoDe-AgeQualiDe prospective cohort study. Aging Clin Exp Res. 2020; 32(7):1295-301. https://doi.org/10.1007/s40520-019-01315-2.

38. Perloff LS. Social comparison and illusions of invulnerability to negative life events. In: Coping with negative life events: Springer; 1987. p. 217-42.

39. Hadwiger M, König H-H, Hajek A. Determinants of frequent attendance of outpatient physicians: a longitudinal analysis using the German socioeconomic panel (GSOEP). Int J Environ Res Public Health. 2019;16(9):1553. https://doi.org/10.3390/ijerph16091553.

40. Hajek A, König H-H. Self-perceptions of ageing, GP visits and frequent attendance. Longitudinal Findings From the German Ageing Survey. Aging Ment Health. 2020;1-6. https://doi.org/10.1080/13607863.2020.1742659.

41. Hajek A, Kretzler B, König H-H. Personality, healthcare use and costs-a systematic review. In: Healthcare: 2020: Multidisciplinary Digital Publishing Institute; 2020. p. 329.

42. Hajek A, Bock J-O, König H-H. Which factors affect health care use among older Germans? Results of the German ageing survey. BMC Health Serv Res. 2017;17(1):30. https://doi.org/10.1186/s12913-017-1982-0.

43. Hajek A, Brettschneider C, Eisele M, Kaduszkiewicz H, Mamone S, Wiese B, et al. Correlates of hospitalization among the oldest old: results of the AgeCoDe-AgeQualiDe prospective cohort study. Aging Clin Exp Res. 2020; 32(7):1295-301. https://doi.org/10.1007/s40520-019-01315-2.

44. Mackelprang JL, Qiu Q, Rivara FP. Predictors of emergency department visits and inpatient admissions among homeless and unstably housed adolescents and young adults. Med Care. 2015;53(12):1010-7. https://doi. org/10.1097/MLR.0000000000000436.

45. Hodgson KJ, Shelton KH, van den Bree MB, Los FJ. Psychopathology in young people experiencing homelessness: a systematic review. Am J Public Health. 2013;103(6):e24-37. https://doi.org/10.2105/AJPH.2013.301318.

46. Specht J, Egloff B, Schmukle SC. Stability and change of personality across the life course: the impact of age and major life events on mean-level and rank-order stability of the big five. J Pers Soc Psychol. 2011;101(4):862-82. https://doi.org/10.1037/a0024950.

47. Barkin SL, Balkrishnan R, Manuel J, Andersen RM, Gelberg L. Health care utilization among homeless adolescents and young adults. J Adolesc Health. 2003:32(4):253-6. https://doi.org/10.1016/S1054-139X(02)00474-3.

48. Bhandari A, Wagner T. Self-reported utilization of health care services: improving measurement and accuracy. Med Care Res Rev. 2006;63(2):21735. https://doi.org/10.1177/1077558705285298.

49. Hajek A, Brettschneider C, Scherer M, Stark A, Kaduszkiewicz H, Weyerer S, et al. Needs and health care costs in old age: a longitudinal perspective: results from the AgeMooDe study. Aging Ment Health. 2020;24(10):1763-8. https://doi.org/10.1080/13607863.2019.1673310.

50. Gudleski GD, Satchidanand N, Dunlap LJ, Tahiliani V, Li X, Keefer L, et al. Predictors of medical and mental health care use in patients with irritable bowel syndrome in the United States. Behav Res Ther. 2017;88:65-75. https://doi.org/10.1016/j.brat.2016.07.006.

51. Stein JA, Andersen RM, Robertson M, Gelberg L. Impact of hepatitis B and C infection on health services utilization in homeless adults: a test of the Gelberg-Andersen behavioral model for vulnerable populations. Health Psychol. 2012;31(1):20-30. https://doi.org/10.1037/a0023643.

52. Hoebel J, Starker A, Jordan S, Richter M, Lampert T. Determinants of health check attendance in adults: findings from the cross-sectional German health update (GEDA) study. BMC Public Health. 2014;14(1):1-12.

53. Lo T, Parkinson L, Cunich M, Byles J. Factors associated with the health care cost in older Australian women with arthritis: an application of the Andersen's Behavioural model of health services use. Public Health. 2016; 134:64-71. https://doi.org/10.1016/j.puhe.2015.11.018.

\section{Publisher's Note}

Springer Nature remains neutral with regard to jurisdictional claims in published maps and institutional affiliations. 